\title{
Cyclic nucleotides in glutamate chemosensory signal transduction of
}

\section{Paramecium}

\author{
W. Q. Yang ${ }^{1}$, C. Braun ${ }^{2}$, H. Plattner ${ }^{2}$, J. Purvee ${ }^{1}$ and J. L. Van Houten ${ }^{1, \star}$ \\ ${ }^{1}$ Department of Biology, University of Vermont, Burlington, VT \\ 2Department of Biology, Universität Konstanz, Konstanz, Germany \\ *Author for correspondence
}

\section{SUMMARY}

Glutamate is an attractant stimulus to Paramecium tetraurelia. It causes a hyperpolarization of the cell and smooth, relatively fast swimming that is characteristic of hyperpolarizing stimuli. We show here that by 1-30 seconds of stimulation, glutamate increases intracellular cAMP. Interestingly, other attractant stimuli, such as acetate and $\mathrm{NH}_{4} \mathrm{Cl}$, that similarly hyperpolarize the cell do not induce an increase in cyclic AMP observable at 30 seconds. In order to determine whether the changes in cyclic AMP could be rapid enough to participate in stimulation as compared to slower processes such as adaptation, rapid kinetic measurements of cyclic AMP were made on whole cells by quenched-flow. We found that, in cells stimulated with glutamate, intracellular cyclic AMP increases by 30 mseconds and peaks at about sevenfold over basal levels by
200 mseconds. Cyclic GMP does not change relative to basal levels over rapid or slower time courses of glutamate stimulation. An antagonist of glutamate, IMP, depolarizes the cells and decreases intracellular cyclic AMP by approx. $\mathbf{5 0 \%}$ and slightly increases cyclic GMP. Results of behavioral tests of cells treated with protein kinase inhibitors also suggest that cyclic AMP is part of the signal transduction pathway for glutamate, but not for other attractant stimuli. These studies are the first demonstration of a possible role for cyclic nucleotide second messengers in an attractant chemosensory transduction pathway in Paramecium.

Key words: Paramecium, Cyclic AMP, Cyclic GMP, Glutamate, Chemoreceptor, IMP

\section{INTRODUCTION}

Glutamate has been recognized as an important intercellular signal molecule for neurotransmission (Tanabe et al., 1992; Wo and Oswald, 1995; Nakanishi, 1992). Perhaps not as well appreciated is that glutamate also serves as an important environmental cue for many different organisms. Lobsters (Carr and Derby, 1986; Fine-Levy et al., 1987), fish (Caprio et al., 1993), and mammals including humans (Yamaguchi, 1987) can detect, that is, taste and/or smell, glutamate among other amino acids. Mammalian taste has the added interesting aspect of synergism of glutamate with 5' ribonucleotides, known as 'umami' taste (Ugawa and Kurihara, 1994; Faurion, 1991). Therefore, it is not unusual that paramecia detect and are attracted to glutamate, which could very well indicate that bacteria, their food, are at hand. Preston and Usherwood (1988) described attraction to glutamate and specific binding sites on cilia. Likewise, in our studies, glutamate is an attractant to $P$. tetraurelia, albeit at higher concentrations than used by Preston. The attractant responses are consistent and robust, as shown in this paper.

Attractants of Paramecium tetraurelia tend to be small molecules that probably indicate the presence of bacteria. Not only glutamate, but also acetate, extracellular cyclic AMP, biotin, folate, and $\mathrm{NH}_{4} \mathrm{Cl}$ are among the stimuli that we have identified (Van Houten, 1978; Van Houten and Preston, 1987; Bell and J. L. Van Houten, unpublished observations). They have in common that they all hyperpolarize cells and cause relatively fast and smooth swimming. Such swimming behavior, with adaptation, causes the accumulation of cells by a biased random walk (Van Houten, 1990).

There are at least three different signal transduction pathways, or at least alternate versions of pathways, and the attractant stimuli acetate, $\mathrm{NH}_{4} \mathrm{Cl}$, and glutamate each stimulate a different pathway. The pathways epitomized by acetate and glutamate are cell surface receptor-mediated, and that epitomized by $\mathrm{NH}_{4} \mathrm{Cl}$ involves intracellular $\mathrm{pH}$ modulation probably without receptor involvement.

Hyperpolarization by altering membrane potential $(\mathrm{Vm})$ through lowering extracellular $\mathrm{K}$ levels has long been demonstrated to elevate Paramecium cyclic AMP levels, and both hyperpolarization and cyclic AMP correlate with increased ciliary beating and rapid swimming (Machemer, 1989; Pech, 1995). Here we show that hyperpolarization of the cells induced not only by altering extracellular $\mathrm{K}$, but also by receptor-mediated processes raises intracellular cAMP levels. What is even more interesting is that this second messenger response is specific to the glutamate pathway; other attractant stimuli that hyperpolarize do not appear to elevate cAMP. 
We also report here that protein kinase inhibitors interfere specifically with attraction to glutamate, which is consistent with the demonstration in this paper that glutamate alone among the attractants tested increases intracellular cyclic AMP. Additionally, we demonstrate that the increase in cyclic AMP occurs rapidly enough to be consistent with a role in the signal transduction pathway as opposed to or perhaps in addition to a role in slower processes such as adaptation. To accomplish the rapid kinetic measurements, we utilized a custom rapid mixing apparatus in order to rapidly stimulate and keep whole cells intact (Knoll et al., 1991, 1992a,b). Other rapid mixing protocols would require broken cells or membranes.

\section{MATERIALS AND METHODS}

\section{Culturing}

Stocks of Paramecium tetraurelia 51-S (sensitive to killer) were grown in wheat grass medium as previously described (Sasner and Van Houten, 1989). Cells for assays of cyclic nucleotides were grown in a supplemented wheat medium (described by Wright et al., 1992).

\section{Slow time-course assays of cyclic AMP}

In general, early stationary stage cells were harvested by centrifugation and washed by centrifugation in basic buffer: $1 \mathrm{mM} \mathrm{CaCl}_{2}, 1 \mathrm{mM}$ MOPS (3- $\{N$-morpholino $\}$ propane sulfonic acid), $1 \mathrm{mM}$ IBMX (1isobutyl-1-methyl xanthine), $0.01 \mathrm{mM}$ EDTA with various salts indicated, adjusted to $\mathrm{pH} 7.2$ with Tris base. (IBMX is added to decrease phosphodiesterase activity. We have previously shown that IBMX does not interfere with the cAMP or cGMP assay by comparing standard curves with and without IBMX.) After the last wash, the cells were resuspended in control solution (basic $\mathrm{CaCl}_{2} / \mathrm{MOPS} / \mathrm{IBMX} / \mathrm{EDTA}$ buffer with $\mathrm{KCl}$ or $\mathrm{NaCl}$ appropriate for that particular control). After 30 minutes, aliquots of the cells were pelleted, and the pellet was transferred by Pasteur pipet and rapidly dispersed into the same control buffer or the basic buffer with stimulus. For example, a pellet of approx. $10^{5}$ cells from control 5 $\mathrm{mM} \mathrm{KCl}$ in buffer would be transferred to buffer with $5 \mathrm{mM} \mathrm{KCl}$ as control for mechanical stimulation or to $5 \mathrm{mM} \mathrm{K}$-L-glutamate as test stimulus.

For a time course beginning at 30 seconds, EDTA was added to aliquots of cells (10 mM EDTA, final concentration, $\mathrm{pH}$ 7.2) to stop cyclic AMP production during a subsequent 2 minute centrifugation. (We determined that this method of stopping the reaction is comparable to rapidly mixing the cells with acid.) The pellet was then homogenized in $10 \mathrm{mM}$ EDTA buffer; two aliquots were taken for protein assays (Pierce Assay using bovine serum albumin as standard). $1 \mathrm{ml}$ was boiled for 4 minutes, and centrifuged at 10,000 $\mathrm{g}$ for 2 minutes. $50 \mu \mathrm{l}$ duplicate aliquots of the supernatant were assayed by the Amersham RIA assay kit and ${ }^{3} \mathrm{H}$-cyclic AMP counts were determined in $3 \mathrm{ml}$ Ready Protein scintillation fluid in a Beckman 2000 scintillation counter.

For time points at 1 second to 30 seconds, cells were not pelleted and transferred but rather were mixed with either more control buffer or stimulus buffer, and rapidly stopped by addition of trichloracetic acid (TCA) to the cells (6\% final concentration). Cells were then vortexed for 1 minute after protein samples were removed. Cell debris was removed by centrifugation at $300 \mathrm{~g}$ for 1 minute and the supernatant was neutralized by washing with water-saturated ether several times until a neutral $\mathrm{pH}$ was achieved. Alternatively, the mixture was neutralized by the addition of concentrated $1.5 \mathrm{M} \mathrm{KOH}$ and $60 \mathrm{mM}$ Hepes buffer to $\mathrm{pH} 7.0$ and centrifuged to remove debris. Duplicate $50 \mu \mathrm{l}$ aliquots of the aqueous layer were assayed by the Amersham RIA kit.
The alternative mixing method was used to simulate the rapid kinetic measurements below, in which cells in control buffer were rapidly mixed with more control buffer or with stimulus. This has an impact on the degree of hyperpolarization that can be achieved in the hyperpolarization control.

Assays were done three times in duplicate and data points were an average of $3 \pm$ one standard deviation or error of the mean, as specified.

\section{Rapid kinetic measurements}

For the rapid kinetic time course, a rapid mixing apparatus was used (Knoll et al., 1991, 1992a,b). Cells were prepared and washed as above and incubated for 30 minutes in the control buffer. $2 \mathrm{ml}$ of cells $\left(10^{5} / \mathrm{ml}\right)$ cells were rapidly mixed with either $2 \mathrm{ml}$ of control buffer or with $2 \mathrm{ml}$ of stimulus buffer. Cells were then rapidly stopped by quenched-flow when they were shot into $20 \%$ ice-cold perchloric acid after $30,100,300,1,000$ or 5,000 mseconds. The mixture was then homogenized and neutralized with cold $1.5 \mathrm{M} \mathrm{KOH} / 60 \mathrm{mM}$ Hepes to $\mathrm{pH}$ 7.0. The mixture was left on ice until the salt precipitated. Half of the supernatant was removed, dried, and stored at $-70^{\circ} \mathrm{C}$. For assays of cyclic AMP, the sample was dissolved in $0.5 \mathrm{ml}$ of $4 \mathrm{mM}$ Tris/EDTA buffer (from the Amersham kit) for 2 hours, centrifuged at $10,000 \mathrm{~g}$ for 2 minutes. $50 \mu \mathrm{l}$ duplicate aliquots were removed for assays.

\section{Assays of cyclic GMP}

Preparation of cells for assays of intracellular cyclic GMP were similar to those for cyclic AMP, with the exception that $100 \mu \mathrm{l}$ duplicate samples of supernatant were taken for assays of cyclic GMP by the Amersham kit protocol. Positive controls also differed, as described in the Results.

\section{T-maze assays of chemoresponse}

Attraction to glutamate was assayed by T-mazes (Van Houten et al., 1982). Cells were distributed in glass stopcocks and the numbers of cells in the arm with test buffer relative to those in the arm with control buffer were used to calculate an index of chemokinesis. Indices $>0.5$ indicate attraction; $<0.5$ indicate repulsion. To test for the effects of kinase inhibitors H8 ([2(methylamino)ethyl]-5-isoquinolinesulfonamide) (Sigma) and H7 (1-[5-isoquinolinylsulfonyl]-2-methylpiperazine) (Sigma), cells were washed in $5 \mathrm{mM}$ $\mathrm{KCl}$ in chemokinesis buffer $\left(1 \mathrm{mM} \mathrm{Ca}(\mathrm{OH})_{2}, 1 \mathrm{mM}\right.$ citric acid, Tris base to $\mathrm{pH} 7.1$ and indicated salt, e.g. $5 \mathrm{mM} \mathrm{KCl}$ ), incubated in 2 $\mathrm{mM} \mathrm{H8}$ or $\mathrm{H} 7$ in $5 \mathrm{mM} \mathrm{KCl}$ chemokinesis buffer for 30 minutes and immediately assayed in T-mazes for attraction to glutamate or acetate. To assay chemoresponse to $\mathrm{NH}_{4} \mathrm{Cl}$, the control solution was $5 \mathrm{mM} \mathrm{NaCl}$ in chemokinesis buffer and the test solution was $5 \mathrm{mM}$ $\mathrm{NH}_{4} \mathrm{Cl}$ in chemokinesis buffer. In the T-mazes, solutions in the arms of the T-maze were matched for $\mathrm{pH}$ and salts and only one pair of ions, e.g. $\mathrm{Cl}^{-}$vs acetate $\left(\mathrm{OAc}^{-}\right)$, differed between the arms of the Tmaze.

\section{RESULTS}

\section{L-glutamate stimulation increases intracellular cyclic AMP}

Cells stimulated by $5 \mathrm{mM}$ K-L-glutamate show, in relatively slow time courses beginning at 30 seconds, increases in cyclic AMP that decline over time in the stimulus, while cells in control solutions with $5 \mathrm{mM} \mathrm{KCl}$ maintain a steady basal level of cyclic AMP (Fig. 1). It has long been known that cells hyperpolarized by changing extracellular cations will increase Paramecium intracellular cyclic AMP (Bonini et al., 1986; Schultz et al., 1984; Majima et al., 1986; Pech, 1995; Schultz and 


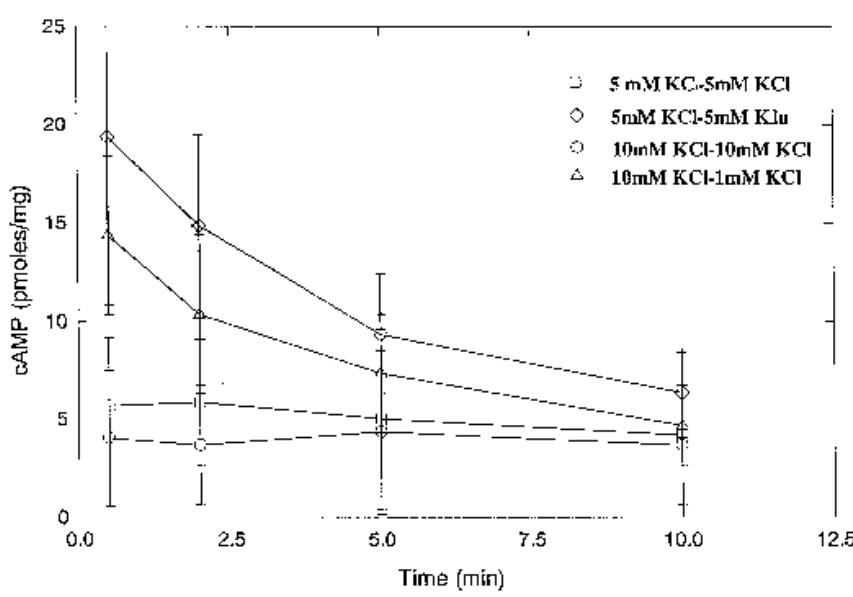

Fig. 1. Time-course measurements of cAMP. Cells were incubated in $5 \mathrm{mM} \mathrm{KCl}$ in basic buffer (see Materials and Methods) and transferred to $(\diamond) 5 \mathrm{mM} \mathrm{K}$-L-glutamate, or to $(\square) 5 \mathrm{mM} \mathrm{KCl}$ for control in basic buffer. Cells were also incubated in $10 \mathrm{mM} \mathrm{KCl}$ in basic buffer and transferred to $(\triangle) 1 \mathrm{mM} \mathrm{KCl}$ (hyperpolarization control) or $10 \mathrm{mM} \mathrm{KCl}$ in basic buffer $(\mathrm{O})$. Samples were then taken for cyclic AMP analysis at 30 seconds to 10 minutes. Data are averages of three experiments in duplicate \pm s.e.m.

Klumpp, 1993). In Fig. 1 there is shown a hyperpolarization control, in which cells are transferred from $10 \mathrm{mM} \mathrm{KCl}$ to 1 $\mathrm{mM} \mathrm{KCl}$. The cells transferred from $10 \mathrm{mM} \mathrm{KCl}$ to $10 \mathrm{mM}$ $\mathrm{KCl}$ serve as the control. The hyperpolarization by manipulation of $\mathrm{K}$ concentrations results in an increase in cyclic AMP that is in agreement with published observations (Bonini et al., 1986; Schultz et al., 1984).

\section{Other stimuli do not increase intracellular cyclic AMP}

Using the slower kinetic protocols, cells treated with glutamate or other stimuli for 30 seconds were assayed for intracellular cyclic AMP (Fig. 2). At these single time points, there is no evidence of increases in cyclic AMP in K-acetate (relative to $\mathrm{KCl}$ control) or $\mathrm{NH}_{4} \mathrm{Cl}$ (relative to $\mathrm{NaCl}$ control) (Fig. 2B), although there is a 2- to 3-fold increase in cAMP in cells stimulated by glutamate (Fig. 2A).

Another stimulus, inosine monophosphate (IMP), decreases cyclic AMP by approximately $50 \%$ at 30 seconds (Fig. 2C). IMP is a repellent that depolarizes the cells and displaces approximately $60 \%$ of ${ }^{3} \mathrm{H}$-glutamate binding to cells (Yang and Van Houten, 1993). L-glutamate inhibits IMP repulsion but not vice versa (Yang and Van Houten, 1993). Depolarization by high $\mathrm{KCl}$ alone also decreases Paramecium cyclic AMP levels by approximately $50 \%$ (Fig. 2C), in agreement with observations from other laboratories (Bonini et al., 1986; Schultz et al., 1984; Majima et al., 1986). The increase in $\mathrm{KCl}$ in the depolarization control would be expected to depolarize the cells approximately $10 \mathrm{mV}$ and IMP to depolarize cells approximately 8-10 $\mathrm{mV}$ (unpublished results).

A glutamate agonist, quisqualate, increases cyclic AMP significantly (by $t$-test) (Fig. 2D). Quisqualate was tested because it alone, among glutamate analogs tested in ${ }^{3} \mathrm{H}$-glutamate binding assays, displaced glutamate and interfered with glutamate chemoresponse (Yang and Van Houten, 1993; Yang, 1995).
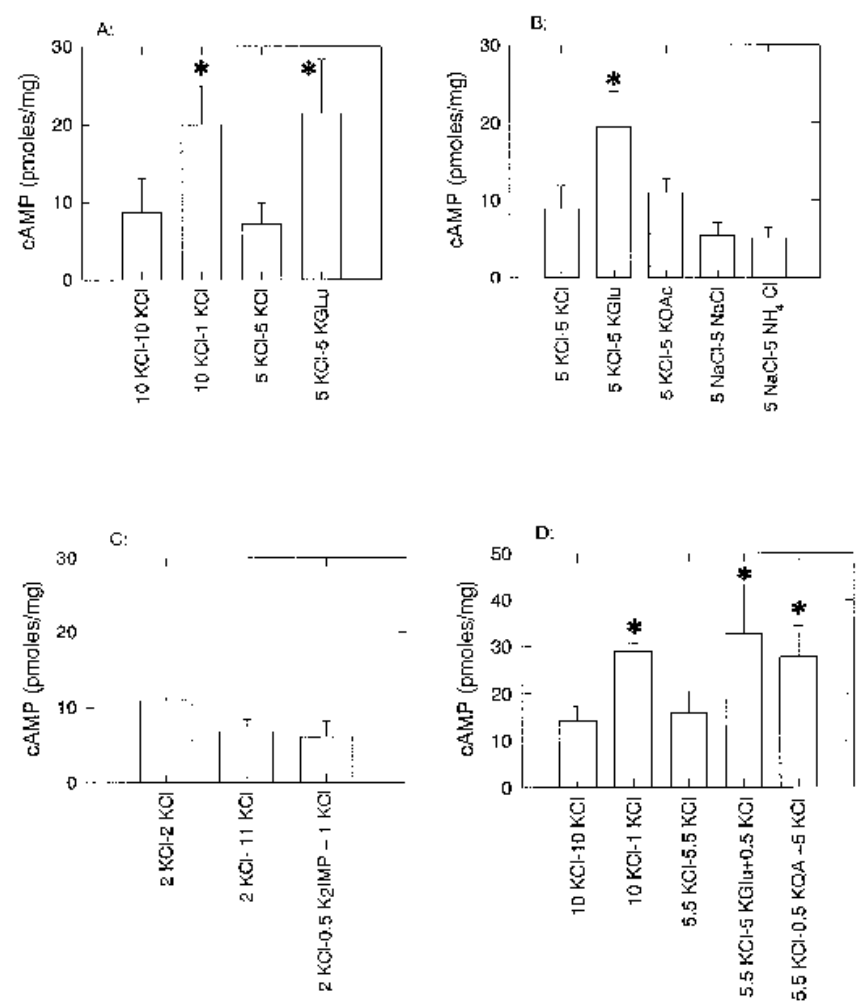

Fig. 2. Cyclic AMP measurements of cells at 30 seconds after stimulation. Glutamate and IMP were tested for their effects on intracellular cAMP. In A-D, labels below bars indicate the solutions from which and to which cells were transferred or mixed. For example, cells in $10 \mathrm{mM} \mathrm{KCl}$ buffer transferred to $1 \mathrm{mM} \mathrm{KCl}$ buffer are indicated $10 \mathrm{KCl}-1 \mathrm{KCl}$. (A) Cells were incubated in $10 \mathrm{mM} \mathrm{KCl}$ in basic buffer and transferred to $10 \mathrm{mM} \mathrm{KCl}$, basic buffer alone (hyperpolarization control); cells were incubated in $5 \mathrm{mM} \mathrm{KCl}$ in basic buffer and transferred to $5 \mathrm{mM} \mathrm{KCl}$ or $5 \mathrm{~K}$-L-glutamate. Data are averages of three experiments in duplicate \pm one s.d. Asterisks indicate statistical significance $(P<0.05)$ using Student's $t$-test. (B) Cells incubated in $5 \mathrm{mM} \mathrm{KCl}$ in basic buffer were transferred to $5 \mathrm{mM} \mathrm{KCl}, 5 \mathrm{mM}$ K-L-glutamate, $5 \mathrm{mM} \mathrm{K}$-OAc. Cells incubated in $5 \mathrm{mM} \mathrm{NaCl}$ were transferred to $5 \mathrm{mM} \mathrm{NaCl}$ or to $5 \mathrm{mM} \mathrm{NH}_{4} \mathrm{Cl}$. Experiments are averages of 3 experiments in duplicate \pm one s.d. (C) Cells were incubated in $2 \mathrm{mM} \mathrm{KCl}$ in basic buffer and mixed for 1 minute with an equal volume of $2 \mathrm{mM} \mathrm{KCl}$ or with $20 \mathrm{mM} \mathrm{KCl}$ (depolarization control) or with $1 \mathrm{mM} \mathrm{K}$ IMP. The final concentrations were $2 \mathrm{mM} \mathrm{KCl}, 11 \mathrm{mM} \mathrm{KCl}$, and $0.5 \mathrm{mM} \mathrm{K}_{2} \mathrm{IMP}+$ $1 \mathrm{mM} \mathrm{KCl}$. Data are averages of 3 experiments in duplicate \pm one s.d. (D) Cells incubated in $5.5 \mathrm{mM} \mathrm{KCl}$ in basic buffer were transferred to $5.5 \mathrm{mM} \mathrm{KCl}$, to $5.0 \mathrm{mM} \mathrm{K}-\mathrm{L}$-glutamate $+0.5 \mathrm{mM}$ $\mathrm{KCl}$, or to $0.5 \mathrm{mM} \mathrm{K}-\mathrm{QA}+5 \mathrm{mM} \mathrm{KCl}$ for 30 seconds. As hyperpolarization control, cells were incubated in $10 \mathrm{mM} \mathrm{KCl}$ and transferred to $1 \mathrm{mM} \mathrm{KCl}$. Asterisk indicates statistically significant difference from control. Data are averages of 3 experiments done in duplicate \pm one s.d. QA, quisqualate.

\section{L-glutamate stimulation increases intracellular cyclic AMP rapidly}

In the slow time-course experiments, cells were transferred in a pellet to the stimulus or control solutions. In order to stimulate and stop stimulation more rapidly, we turned to a rapid mixing and quenching protocol. The cells in this experimental design cannot be moved from pure control to pure 
stimulus solutions, because mixing of cells with stimulus solution is required. For example, in the experiment in Fig. 1 in which a pellet is moved from control solution to the same (control) or stimulus solution, the control is $5 \mathrm{mM} \mathrm{KCl}$ (squares) and stimulus is $5 \mathrm{mM} \mathrm{K}$-L-glutamate (diamonds). In Fig. 3, cells are in control solution $10 \mathrm{mM} \mathrm{KCl}$ and are mixed 1:1 with more $10 \mathrm{mM} \mathrm{KCl}$ or with $10 \mathrm{mM} \mathrm{K}$-L-glutamate, in the latter to achieve a $5 \mathrm{mM}$ L-glutamate with $\mathrm{K}^{+}$unchanging at $10 \mathrm{mM}$. In Figs 1 and 3, the cells are stimulated with the same concentration of glutamate, but in different ionic backgrounds. Also, the hyperpolarization control in Fig. 1 is achieved by moving cells from $10 \mathrm{mM} \mathrm{KCl}$ to $1 \mathrm{mM} \mathrm{KCl}$. In Fig. 3, cells experience a dilution by mixing from $10 \mathrm{mM} \mathrm{KCl}$ to $5 \mathrm{mM} \mathrm{KCl}$ because this is the limit of concentration change that can be achieved by mixing $1: 1$, and thus the degree of hyperpolarization is not as great in Fig. 3 as in Fig. 1. This is a necessary consequence of mixing as opposed to moving a pellet of cells to a new solution to begin a time course.

Regardless of the difference between the two experimental paradigms for Fig. 1 and Fig. 3, the experimental results can be compared because the levels of cAMP in cells in control 10 $\mathrm{mM} \mathrm{KCl}$ are similar in both experimental situations. Additionally, it is evident in both Figs that cAMP levels increase in cells stimulated with glutamate or hyperpolarized by lowering $\mathrm{KCl}$. The absolute levels of elevated cAMP differ between Figs 1 and 3 , in part because in Fig. 1 we are witnessing only the declining phase of the cAMP stimulation and in part because the background ionic conditions are different as described above.

Fig. 3 demonstrates that cells show increases in cyclic AMP by 30 mseconds in glutamate, and a peak increase by 200 mseconds. The levels in intracellular cyclic AMP decline after this time although the cells remain in L-glutamate.

As discussed, the hyperpolarization control in Fig. 3 differs

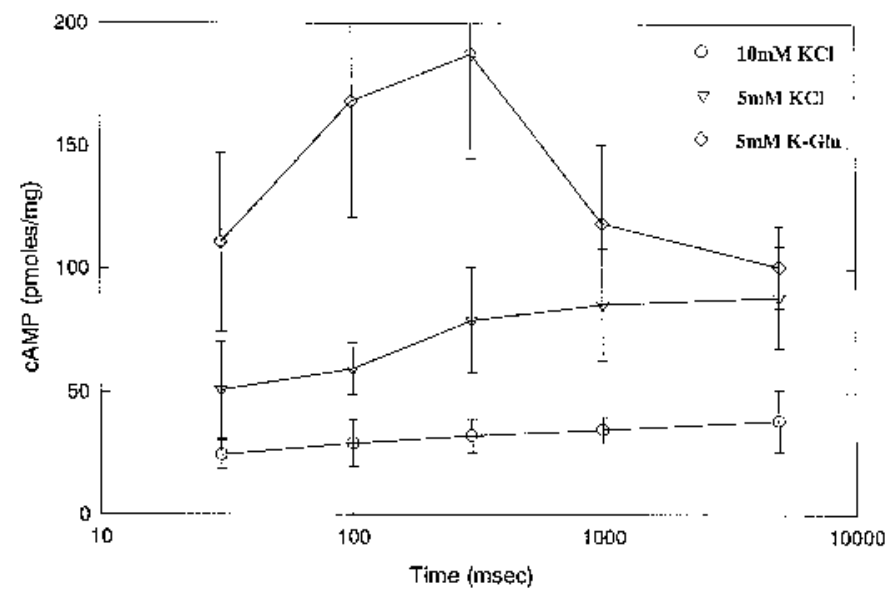

Fig. 3. Rapid kinetic measurements of cAMP. Cells incubated in basic buffer with $10 \mathrm{mM} \mathrm{KCl}$ (see Materials and Methods) were rapidly mixed with equal volume of either basic buffer or test solution and collected in PCA after 30 to 5,000 mseconds. (O) Cells incubated in and mixed with $10 \mathrm{mM} \mathrm{KCl} ;(\diamond)$ cells incubated in 10 $\mathrm{mM} \mathrm{KCl}$ and mixed with $10 \mathrm{mM} \mathrm{K}$-L-glutamate; $(\nabla)$ cells incubated in $10 \mathrm{mM} \mathrm{KCl}$ and mixed with basic buffer alone. Final concentrations in the mixing chambers were $(\bigcirc) 10 \mathrm{mM} \mathrm{KCl} ;(\diamond) 10$ $\mathrm{mM} \mathrm{K}+, 5 \mathrm{mM} \mathrm{L}$-glutamate, $5 \mathrm{mM} \mathrm{Cl}^{-} ;(\nabla) 5 \mathrm{mM} \mathrm{KCl}$ hyperpolarization control.
Table 1. Effects of $\mathbf{H 7}$ and $\mathrm{H8}$ on chemoresponse

\begin{tabular}{lccc}
\hline & \multicolumn{3}{c}{ T-maze results } \\
\cline { 2 - 4 } Pretreatment & K-OAc & K-glutamate & $\mathrm{NH}_{4} \mathrm{Cl}$ \\
\hline Buffer & $0.75 \pm 0.09$ & $0.68 \pm 0.11$ & \\
H8 & $0.77 \pm 0.13$ & $0.53 \pm 0.19^{*}$ & \\
Buffer & & $0.71 \pm 0.07$ & $0.78 \pm 0.06$ \\
H8 & & $0.43 \pm 0.13^{*}$ & $0.81 \pm 0.04$ \\
Buffer & $0.74 \pm 0.10$ & $0.76 \pm 0.08$ & nd \\
H7 & $0.70 \pm 0.14$ & $0.57 \pm 0.21^{*}$ & nd
\end{tabular}

Cells were incubated in control chemokinesis buffer appropriate for the Tmaze or in $\mathrm{H} 7$ or $\mathrm{H} 8$ in the same buffer for 15-25 minutes and tested in Tmazes. nd, not determined.

T-maze results of tests of $5 \mathrm{mM} \mathrm{K}-\mathrm{OAc}$ or $5 \mathrm{mM} \mathrm{K}$-L-glutamate vs $5 \mathrm{mM}$ $\mathrm{KCl}$, and $5 \mathrm{mM} \mathrm{NH}_{4} \mathrm{Cl}$ vs $5 \mathrm{mM} \mathrm{NaCl}$.

Data are averages of 6-12 T-mazes \pm one s.d. (representing at least 3 populations of cells). Asterisk indicates statistically significant differences from controls (buffer pretreatment) by the Mann-Whitney U test.

from that in Fig. 1. Cells are incubated in $10 \mathrm{mM} \mathrm{KCl}$ control and mixed with buffer devoid of $\mathrm{KCl}$ to achieve $5 \mathrm{mM} \mathrm{KCl}$. Cyclic AMP appears to increase by 30 mseconds and continues to increase from that time, but more slowly than for the L-glutamate treated cells. Nonetheless, there is an increase in cyclic AMP by hyperpolarization by lowering $\mathrm{K}$ alone. The $10 \mathrm{mM} \mathrm{KCl}$ control serves as control for both the hyperpolarization in $5 \mathrm{mM} \mathrm{KCl}$ and in the stimulus $5 \mathrm{mM} \mathrm{L}$ glutamate.

\section{Protein kinase inhibitors specifically affect chemoresponse to L-glutamate}

The rapid kinetic results imply that cyclic AMP can, indeed, participate in stimulus transduction of L-glutamate. To further probe the role of cyclic AMP in signal transduction, we treated cells with protein kinase inhibitors that are known to affect protein kinase $\mathrm{A}$ in addition to other kinases (Hidaka et al., 1984). Paramecium tetraurelia has been shown to have protein kinase A (Hochstrasser and Nelson, 1989) and there is the distinct possibility that this enzyme participates in chemosensory signal transduction. Therefore, cells treated with $\mathrm{H} 8$ and $\mathrm{H} 7$ were tested for chemoresponse to L-glutamate and two stimuli, acetate and $\mathrm{NH}_{4} \mathrm{Cl}$, that did not appear to affect cyclic AMP levels. Cells treated with $\mathrm{H} 8$ or $\mathrm{H} 7$ are selectively defective in attraction to L-glutamate and appear to be normally attracted to $\mathrm{K}-\mathrm{OAc}$ and $\mathrm{NH}_{4} \mathrm{Cl}$ (Table 1).

\section{Cyclic GMP is not affected by L-glutamate}

Cells stimulated with L-glutamate do not statistically significantly change intracellular cyclic GMP levels (Table 2). Depolarization with $\mathrm{BaCl}_{2}$ increases cyclic GMP (Table 2), as expected from and consistent with the results of others (Bonini et al., 1986; Majima et al., 1986; Pech, 1995; Schultz and Klumpp, 1993; Schultz et al., 1986; Schultz and Schade, 1989). IMP, which depolarizes the cells, might be expected likewise to increase intracellular cyclic GMP. In rapid kinetic measurements, or slower time courses, IMP increases intracellular cyclic GMP only slightly, but statistically significantly (by the Student's $t$-test). We found no evidence that acetate affects cGMP at 30 and 100 mseconds (20.5 and 19.0 pmoles cyclic $\mathrm{GMP} / \mathrm{mg}$ protein, compare to Table $2 \mathrm{KCl}$ controls at 30 and 100 mseconds). 
Table 2. Cyclic GMP (pmoles/mg protein)

\begin{tabular}{|c|c|c|c|c|c|}
\hline Control & Stimulus & 100 mseconds & 1 second & 5 seconds & 10 seconds \\
\hline \multicolumn{6}{|l|}{ (A) } \\
\hline $\mathrm{KCl}$ & $\mathrm{KCl}$ & $15.7 \pm 0.7$ & $19.8 \pm 0.3$ & $18.2 \pm 1.7$ & \\
\hline $\mathrm{KCl}$ & K-Glutamate & $20.1 \pm 0.3$ & $18.2 \pm 2.7$ & $18.2 \pm 1.8$ & \\
\hline \multicolumn{6}{|l|}{ (B) } \\
\hline $\mathrm{KCl}$ & $\mathrm{KCl}$ & $21.2 \pm 2.0$ & $21.5 \pm 1.0$ & $23.4 \pm 0.8$ & $28.6 \pm 0.4$ \\
\hline $\mathrm{KCl}$ & $\mathrm{K}_{2} \mathrm{IMP}$ & $39.0 \pm 0.8$ & $36.4 \pm 1.8^{*}$ & $40.7 \pm 1.9 *$ & $28.7 \pm 0.7$ \\
\hline \multicolumn{6}{|l|}{ (C) } \\
\hline
\end{tabular}

(A) Cells in $10 \mathrm{mM} \mathrm{KCl}$ are mixed 1:1 with more $10 \mathrm{mM} \mathrm{KCl}$ or with $10 \mathrm{mM} \mathrm{K}$-glutamate. Data are averages of 4 experiments in duplicate \pm one s.e.m. (B) Cells in $2 \mathrm{mM} \mathrm{KCl}$ are mixed with more $2 \mathrm{mM} \mathrm{KCl}$ or with $1 \mathrm{mM} \mathrm{K}_{2} \mathrm{IMP}$ yielding a stimulus solution of $0.5 \mathrm{mM} \mathrm{K}_{2} \mathrm{IMP}+2 \mathrm{mM} \mathrm{K}^{+}+1 \mathrm{mM} \mathrm{Cl}^{-}$. Data at 1 and 5 seconds are averages of 4 experiments in duplicate \pm s.e.m.; at 100 mseconds and 10 seconds, data are averages of 2 experiments in duplicate \pm range. The data at 1 and 5 seconds show a significant difference between cyclic GMP levels in test and control (by $t$-test).

(C) Cells in basic buffer (see Materials and Methods) are mixed with more buffer or $6 \mathrm{mM} \mathrm{BaCl}_{2}$ to yield a stimulus solution of $3 \mathrm{mM} \mathrm{BaCl}_{2}$. Data are averages of 2 experiments in duplicate \pm range.

\section{DISCUSSION}

In the experiments shown above we have demonstrated that the stimulus L-glutamate rapidly increases intracellular levels of cyclic AMP. The positive control for increasing cyclic AMP is a hyperpolarization brought about by reducing extracellular $\mathrm{KCl}$ and this control in our hands reliably induces an increase in intracellular cyclic AMP, as expected from previous work in other laboratories (Bonini et al., 1986; Schultz et al., 1984; Pech, 1995; Schultz and Klumpp, 1993).

Other than glutamate, stimuli that hyperpolarize the cells, such as $\mathrm{K}$-acetate and $\mathrm{NH}_{4} \mathrm{Cl}$, do not increase cyclic AMP. While we have not done the extensive time courses at short stimulation times that we have done for glutamate, none of our studies of acetate and $\mathrm{NH}_{4} \mathrm{Cl}$ have ever shown any change in cyclic nucleotide level. Therefore, these stimuli either cause a more transient $(<30$ seconds) change in cyclic nucleotide levels than glutamate or they cause no change at all. Either result is very distinct from the results with glutamate, yet all of these stimuli, in the concentrations used in these studies, hyperpolarize the cells to approximately the same extent (approx. 8-10 mV) and sustain this hyperpolarization. Thus, it is interesting that not all hyperpolarizations are interpreted by the cells in the same way. Some seem to be associated with activation of the adenylyl cyclase (or inhibition of phosphodiesterase) while others are not.

Depolarization by $\mathrm{BaCl}_{2}$ or IMP increase cyclic GMP on a different time course from the stimulus-induced increases in cyclic AMP (Fig. 3; Table 2). L-glutamate does not affect cyclic GMP levels (Table 2). However, IMP, which depolarizes the cells, does decrease cyclic AMP approximately 50\%, similar to the effects of the depolarization control, and only slightly increases cyclic GMP. IMP may decrease adenylyl cyclase activity indirectly by depolarization or by coupling of a glutamate/IMP receptor to the cyclase. These experiments do not enlighten us about the mechanism, but do imply that there is a basal level of adenylyl cyclase activity that is stimulated by glutamate and decreased by IMP. Glutamate appears to have two specific binding sites, one of which is displaced by IMP (Yang and Van Houten, 1993). The relationship between the binding sites to the adenylyl cyclase effects remains to be demonstrated.

The effects of L-glutamate on intracellular cyclic AMP are rapid, robust and reproducible implying a possible role for cyclic AMP in the signal transduction pathway. To probe this idea in preliminary experiments, inhibitors of kinases were used to treat cells before assays of chemoresponse behavior. Responses to L-glutamate were specifically inhibited compared to responses to $\mathrm{K}$-acetate and $\mathrm{NH}_{4} \mathrm{Cl}$. While it is understood that inhibitors such as $\mathrm{H} 7$ and $\mathrm{H} 8$ will have non-specific effects or effects on kinases other than protein kinase $\mathrm{A}$, it is noteworthy that the effects of these inhibitors seem to be stimulusspecific for Paramecium chemoresponse. If there were general effects on ciliary motility, one might expect that all of the stimuli would be affected instead of only L-glutamate.

The coupling between putative L-glutamate binding sites (Yang and Van Houten, 1993) and adenylyl cyclase or phosphodiesterase is not known at this time. One scenario is that the coupling of the glutamate receptor to the adenylyl cyclase is through the hyperpolarization. The cyclic AMP second messenger would then have effects on axonemal function and ciliary motility through the activity of specific kinases (see Pech, 1995, for a review). The adenylyl cyclase of Paramecium tetraurelia is thought to be responsive to membrane potential and perhaps is an ion channel itself (Schultz et al., 1992).

The scenario above does not explain the failure of some chemical stimuli that are known to hyperpolarize to increase cyclic AMP levels. Clearly these hyperpolarizations are not sensed by the adenylyl cyclase (or phosphodiesterase) or the order of events in the scenario is wrong. Perhaps the glutamate receptor couples to an adenylyl cyclase and intracellular cyclic nucleotides directly gate an ion channel, for which there is no evidence yet in Paramecium. There are reports of vertebrate metabotropic L-glutamate receptors coupled to adenylyl cyclase, presumably through $\mathrm{G}$ proteins that activate the cyclase (Winder and Conn, 1992; Winder and Conn, 1993). However, there is scant evidence for trimeric G proteins in Paramecium at this time (Forney and Rodkey, 1992; Fraga and Hinrichsen, 1994). Alternatively, cyclic AMP could change membrane potential indirectly through the activation of protein kinase A and its action on a substrate such as a channel or ion pump.

Cyclic nucleotides have been found to influence ciliary beating patterns in Paramecium and the levels of the cyclic nucleotides have been shown to be related to membrane 
potential changes (reviewed by Pech, 1995). In general hyperpolarization (for example by lowering $\mathrm{KCl}$ ), increased intracellular cAMP levels and increased ciliary beating frequency are all correlated. Depolarization (for example achieved by increasing $\mathrm{KCl}$ or $\mathrm{BaCl}_{2}$ ), decreased cAMP, increased cGMP and slow ciliary beating are also correlated. However, there is no consensus as yet for the cause and effect order for the cyclic nucleotide levels and membrane potential changes, but both contribute to ciliary beat pattern (see Pech, 1995). The interesting aspect for the study of chemical stimuli is the imperfect correlation that we have found between hyperpolarization by chemical stimuli and elevation of intracellular cAMP.

In summary, there appear to be at least three pathways for chemosensory signal transduction in Paramecium tetraurelia. Glutamate initiates a pathway that includes cyclic AMP as a second messenger; acetate and $\mathrm{NH}_{4} \mathrm{Cl}$ initiate pathways that do not include cyclic AMP as a second messenger, at least not on the same time course, yet all three stimuli hyperpolarize the cells. The cyclic nucleotide levels rise rapidly enough after glutamate stimulation to be part of the signal transduction pathway. Studies with inhibitors of protein kinases that include those stimulated by cyclic nucleotides support this notion. This is the first demonstration of a cyclic nucleotide second messenger resulting from a receptor-mediated signal transduction in Paramecium.

This work is supported by NIH and the VCC to J.V.H. and grant N 78/11 from the Deutsche Forschungsgemeinschaft (to H.P.). We thank F. Hecht for technical assistance. Thanks go to Dr J. Schultz for suggestions regarding the cyclic AMP assay and to J. Stabila and C. Paquette for figure preparation.

\section{REFERENCES}

Bonini, N., Gustin, M. C. and Nelson, D. L. (1986). Regulation of ciliary motility by membrane potential in Paramecium. Cell Motil. Cytoskel. 6, 256-272.

Caprio, J., Brand, J. G., Teeter, J. H., Valentincic, T., Kalinoski, D. L., Kohbara, J., Kumazawa, T. and Wegert, S. (1993). Trends Neurosci. 16, 192-197.

Carr, W. E. S. and Derby, C. D. (1986). Behavioral characterization for the shrimp, Palaemonetes pugio: Identification of active components in food extracts and evidence of synergistic mixture interactions. Chem. Senses 11, 49-64.

Fine-Levy, J. B., Derby, C. D. and Daniel, P. C. (1987). Chemosensory discrimination behavioral abilities of the spiny lobster. Ann. NY Acad. Sci. 510, 280-283.

Faurion, A. (1991). Are umami taste receptor sites structurally related to glutamate CNS receptor sites? Physiol. \& Behavior 49, 905-912.

Forney, J. and Rodkey, K. (1992). A repetitive DNA sequence in Paramecium macronuclei is related to the $\beta$ subunit G proteins. Nucl. Acids Res. 20, 53875402 .

Fraga, D. and Hinrichsen, R. (1994). The identification of a complex family of low-molecular-weight GTP-binding protein homologues from Paramecium tetraurelia by PCR cloning. Gene 147, 145-148.

Hidaka, H., Inagaki, M., Kawamoto, S. and Sasaki, Y. (1984). Isoquinolinesulfonamides, novel and potent inhibitors of cyclic nucleotide dependent protein kinase and protein kinase C. Biochemistry 23, 5036-5041.

Hochstrasser, M. and Nelson, D. L. (1989). Cyclic AMP-dependent protein kinase in Paramecium tetraurelia. J. Biol. Chem. 264, 14510-14518.

Knoll, G., Braun, C. and Plattner, H. (1991). Quenched flow analysis of exocytosis in Paramecium cells: Time course, changes in membrane structure, and calcium requirements revealed after rapid mixing and rapid freezing of intact cells. J. Cell Biol. 113, 1295-1304.

Knoll, G., Braun, C., Müller, T. and Plattner, H. (1992a). Time-resolved analysis of rapid events in intact cells. Electron Microsc. 3, 37-41.

Knoll, G., Kerboeuf, D. and Plattner, H. (1992b). A rapid calcium influx during exocytosis in Paramecium cells is followed by a rise in cyclic GMP within 1s. FEBS Lett. 304, 265-268.
Machemer, H. (1989). Cellular behavior modulated by ions: electrophysiological implications. J. Protozool. 36, 463-487.

Majima, T., Hamasaki, T. and Arai, T. (1986). Increase in cellular cyclic GMP level by potassium stimulation and its relation to ciliary orientation in Paramecium. J. Comp. Physiol. 92, 293-319.

Nakanishi, S. (1992). Molecular diversity of glutamate receptors and implications for brain function. Science 258, 597-603.

Nakaoka, Y. and Machemer, H. (1990). Effects of cyclic nucleotides and intracellular Ca on voltage-activated ciliary beating in Paramecium. J. Comp. Physiol. 166, 401-406.

Pech, L. (1995). Regulation of ciliary motility in Paramecium by cAMP and cGMP. Comp. Biochem. Physiol. 111A 31-37.

Preston, R. R. and Usherwood, P. N. R. (1988). L-glutamate-induced membrane hyperpolarization and behavioral responses in Paramecium tetraurelia. J. Comp. Physiol. A 158, 345-351.

Sasner, M. J. and Van Houten, J. L. (1989). Evidence for a Paramecium folate chemoreceptor. Chem. Senses 14, 587-595.

Schultz, J. E., Grünemund, R., von Hirschausen, R. and Schönfeld, U. (1984). Ionic regulation of cyclic AMP levels in Paramecium tetraurelia in vivo. FEBS Lett. 167, 113-116.

Schultz, J. E., Pohl, T. and Klumpp, S. (1986). Voltage gated $\mathrm{Ca}^{2+}$ entry into Paramecium linked to intracellular increase in cyclic GMP. Nature 322, 271273.

Schultz, J. E. and Schade, U. (1989). Calcium channel activation and inactivation in Paramecium biochemically measured by cyclic GMP production. J. Membr. Biol. 109, 259-267.

Schultz, J. E., Klumpp, S., Benz, R., Schürhoff-Goeters, W. J. Ch. and Schmid, A. (1992). Regulation of adenylyl cyclase from Paramecium by an intrinsic potassium conductance. Science 255, 600-603.

Schultz, J. E. and Klumpp, S. (1993). Cyclic nucleotides and calcium signaling in Paramecium. Advan. Second Messenger Phosphoprotein Res. 27, 25-46.

Tanabe, Y., Masu, M., Ishii, T., Shigemoto, R. and Nakanishi, S. (1992). A family of metabotropic glutamate receptors. Neuron 8, 169-179.

Ugawa, T. and Kurihara, K. (1994). Enhancement of canine taste responses to umami substances by salts. J. Physiol. 363, R944-R949.

Van Houten, J. L. (1978). Two mechanisms of chemotaxis in Paramecium. J. Comp. Physiol. A 127, 167-174.

Van Houten, J. L., Martel, E. and Kasch, T. (1982). Kinetic analysis of chemokinesis of Paramecium. J. Protozool. 29, 226-230.

Van Houten, J. L. and Preston, R. R. (1987). Chemoreception in single-celled organisms. In Neurobiology of Taste and Smell (ed. T. E. Finger), pp. 11-38. John Wiley \& Sons.

Van Houten, J. L. (1990). Chemosensory transduction in Paramecium. In Biology of the Chemotactic Response (ed. J. Armitage and J. Lackie), pp. 297-322. Cambridge University Press, Cambridge.

Van Houten, J. L. (1994). Chemosensory transduction in eukaryotic microorganisms: Trends for neuroscience? Trends Neurosci. 17, 62-71.

Winder, D. G. and Conn, P. J. (1992). Activation of metabotropic glutamate receptors in the hippocampus increases cyclic AMP accumulation. $J$. Biochem. 59, 375-378.

Winder, D. G. and Conn, P. J. (1993). Activation of metabotropic glutamate receptors increases cAMP accumulation in hippocampus by potentiating responses to endogenous adenosine. J. Neurosci. 13, 38-44.

Wo, Z. G. and Oswald, R. E. (1995). Unraveling the modular design of glutamate-gated ion channels. Trends Neurosci. 18, 161-168.

Wright, M. V., Frantz, M. and Van Houten, J. L. (1992). Lithium fluxes in Paramecium and their relationship to chemoresponse. Biochim. Biophys. Acta 1107, 241-251.

Yamaguchi, S. (1987). Basic properties of umami tase and effects on humans In Umami: A Basic Taste. (ed. Y. Kawamura and M. R. Kare), pp. 41-73. Marcel Dekker, NY.

Yamaguchi, S. (1991). Basic properties of umami and effects on humans. Physiol. Behavior 49, 833-841.

Yang, W. Q. and Van Houten, J. L. (1993). Signal transduction of glutamate and IMP in Paramecium. Soc. Neurosci. Abstr. 19, 1429.

Yang, W. Q. (1995). Identification and characterization of glutamate and IMP receptors and their signal transduction in Paramecium tetraurelia. $\mathrm{PhD}$ thesis, University of Vermont.

(Received 7 March 1997 - Accepted 10 July 1997) 